\title{
Heavy metals in urinary stones in the Democratic Republic of Congo
}

\author{
Pablo Kuntima Diasiama Diangienda ${ }^{1 *} \mathbb{C}$, Dieudonné Molamba Moningo ${ }^{1}$, Alain Ngoma Mayindu², \\ Jean-Philippe Haymann ${ }^{3}$ and Michel Daudon ${ }^{3}$
}

\begin{abstract}
Background: The Democratic Republic of Congo has been a country of intensive mining activities for centuries, but the data on the presence of heavy metals in stones are lacking. This study aimed to identify different heavy metals in urinary tract stones and to investigate their association with the main components of urinary stones.

Methods: Thirty-six stones from urolithiasis patients $(n=36)$ followed in 10 hospitals in the Democratic Republic of Congo between January 2016 and September 2019 were analyzed by Fourier transform infrared spectrophotometry. Further analysis using X-ray fluorescence was conducted at the Laboratory of Solids Physics.

Results: Eight heavy metals were detected in all the stones analyzed. The average (SD) number of heavy metals detected by stone was 5 (1.2). Iron and strontium were detected in all the stones analyzed. Other heavy metals detected included zinc, copper, bromine, rubidium, lead and nickel. Rubidium had the highest concentration in the stones regardless of the sampling site. There was no statistically significant association between the content of heavy metals at the center level and at the crown level of the stones. Rubidium had more affinity with phosphates and purines $\left(p^{<} 0.001\right)$. Iron and strontium exhibited a high affinity with weddellite than with whewellite.
\end{abstract}

Conclusion: Iron and Strontium were present in all stones analyzed. The presence of heavy metals in stones analyzed might suggest environmental pollution rather than crystalline induction factors.

Keywords: Urinary stone, Chemical composition, Heavy metals, Environmental pollution

\section{Background}

The presence of heavy metals in urinary stones and their role in crystal induction remain poorly understood [14]. They may play a role in crystal induction, depending on the links between heavy metals and solutes capable of crystallizing in urine. Some studies reported that a higher content of metals in the nucleus rather than in the peripheral layers of stones might have a possible lithogenic effect $[1,2,5]$.
Other studies reported that these metals had little influence in lithogenesis and they would rather be considered as biomarkers of environmental exposure $[1,6]$.

In addition, several studies have demonstrated the link between traces of heavy metals and the chemical and crystalline composition of stones [7, 8]. The inorganic components (calcium oxalate and phosphates) being more loaded by these heavy metals unlike the organic components (uric acid and cystine) which have a low content $[1,7,8]$.

Although a few studies have investigated the heavy metal content in urinary stones by physical methods $[1$, $4-6,9-14]$, we could not find such a study conducted in Central Africa, particularly in the Democratic Republic of Congo (DRC). The DRC has been a country of intensive mining activities for centuries. Over the last decades,

*Correspondence: pablodiang@gmail.com

${ }^{1}$ Department of Urology, Kinshasa University Hospital, Faculty of Medicine, University of Kinshasa, Kinshasa, Democratic Republic of Congo

Full list of author information is available at the end of the article 
these activities have increased, largely because of the need for copper, cobalt and other metals for the industrial development of fast-growing Asian economies and lithium-ion batteries. Consequently, there is widespread contamination of the environment by various heavy metals. In this context, several studies revealed health problems linked to exposure to heavy metals in miners and inhabitants of mining areas [15-18]. Thus, this study aimed to identify different heavy metals in urinary tract stones and to investigate their association with the main components of urinary stones.

\section{Methods}

Thirty-six stones from urolithiasis patients admitted to 10 hospitals in the DRC, who provided informed consent for this study between January 2016 and September 2019, were analyzed at the Functional Explorations Department of a Parisian hospital by transform infrared spectrophotometry de Fourier (Vector 22 FT-IR spectrophotometer, Bruker Optics, Champs-sur-Marne, France) in absorbance mode by accumulation of 32 spectra between 4000 and $400 \mathrm{~cm}^{-1}$, with a resolution of $4 \mathrm{~cm}^{-1}$.

Further analyzes by X-ray fluorescence were carried out at the Laboratory of Solids Physics, Bat.510, Université Paris-Sud, 91,405 Orsay using the MORPHEUS X-ray scattering experiment platform. We used the molybdenum rotary anode generator (with energies close to $17.48 \mathrm{keV}$ ) at $45 \mathrm{kV}-20 \mathrm{~mA}$. The beam dimension was equal to $150 \times 150 \quad \mu^{2}$ and the measurement time was 30 to $60 \mathrm{~min}$. For each stone, two measurement points were examined (the heart of the stone when the nucleus was individualized and the crown or the outer layer) to assess the zonal distribution of the metals. The metal / calcium ratio allowed the evaluation of the heavy metal content in the crown and the core of each stone analyzed.

These 36 stones were randomly drawn from a total of 194 stones analyzed at the TENON Hospital in Paris. Only two patients whose stones were selected resided in provinces of the DRC (known to be mining areas) and the rest lived in Kinshasa.

\subsection{Study parameters}

We determined the main composition (chemical or crystalline body representing the large proportion in each stone) of each stone analyzed and grouped them based on their chemical family: calcium oxalate, phosphate (including struvite) and purine.

Demographic variables collected for the study included age, sex, place of residence and province of origin. The place of residence was divided into two categories: Kinshasa and other provinces. Provinces were categorized into 4 geographic groups: West, North, Center-South and East.

\subsection{Statistical analysis}

Continuous variables were expressed as means and medians. Categorical variables were summarized into proportions. Differences in categorical variables between groups were assessed using chi-square test or the chi-square likelihood ratio as appropriate. Differences in means were assessed by the student's t test. $P$ values less or equal to 0.05 were interpreted as statistically significant. Statistical analysis was performed using SPSS Statistics software version 22 (IBM, Armonk, USA).

\section{Results}

\subsection{General characteristics of the population}

Overall, the mean (SD) age of patients was 47.4 (19.6) years; $22(61.1 \%)$ patients were males with a male-tofemale ratio of 1.5: 1; Twenty-two patients (61.1\%) had upper urinary tract stones. Patients younger than 19 years $(p<0.001)$ and those older than 60 years $(p=0.017)$ had lower tract stones than other age groups. Thirty-one patients (86.1\%) lived in the city of Kinshasa. Most patients came from the provinces of the West (15 patients) and Center-South (14 patients) of the country (Table 1).

Large diameter $31 \mathrm{~mm}$ stone extracted from a patient's bladder after cystolithotomy. It is predominantly composed of anhydrous acid and has crystals of 6.9 hydroxy methyl acids (HMA) on its surface. Stone was analyzed

Table 1 General characteristics of patients

\begin{tabular}{|c|c|c|c|c|}
\hline \multirow[t]{2}{*}{ Variables } & \multicolumn{2}{|c|}{ Site of stones } & \multirow[t]{2}{*}{ All $n=36(\%)$} & \multirow[t]{2}{*}{$p$} \\
\hline & $\begin{array}{l}\text { Upper } \\
\text { tract } \\
n=22(\%)\end{array}$ & $\begin{array}{l}\text { Lower } \\
\text { tract } \\
n=14(\%)\end{array}$ & & \\
\hline Age (years) & & & & $<0.001^{*}$ \\
\hline$\leq 19$ & $0(0.0)$ & $3(21.4)$ & $3(8.3)$ & \\
\hline $20-39$ & $7(31.8)$ & $2(14.3)$ & $9(25.0)$ & \\
\hline $40-59$ & $12(54.5)$ & $1(7.1)$ & $13(36.1)$ & \\
\hline$\geq 60$ & $3(13.6)$ & $8(57.1)$ & $11(30.6)$ & \\
\hline Sex & & & & 0.017 \\
\hline Females & $12(54.5)$ & $2(14.3)$ & $14(38.9)$ & \\
\hline Males & $10(45.5)$ & $12(85.7)$ & $22(61.1)$ & \\
\hline Residence & & & & 0.287 \\
\hline Kinshasa & $20(90.9)$ & $11(78.6)$ & $31(86.1)$ & \\
\hline Other provinces & $2(9.1)$ & $3(21.4)$ & $5(13.9)$ & \\
\hline Province of origin & & & & 0.043 \\
\hline Western & $11(50.0)$ & $4(28.6)$ & $15(41.7)$ & \\
\hline North & $1(4.5)$ & $5(35.7)$ & $6(16.7)$ & \\
\hline Center-south & $10(45.5)$ & $4(28.6)$ & $14(38.9)$ & \\
\hline Eastern & $0(0.0)$ & $1(7.1)$ & $1(2.8)$ & \\
\hline
\end{tabular}

* Likelihood ratio chi-square 
at two points by $\mathrm{X}$-ray fluorescence with a fluorescence spectrum to detect $\mathrm{K}, \mathrm{Ca}$, iron, copper, $\mathrm{Zn}, \mathrm{Br}, \mathrm{Rb}$ and $\mathrm{Sr}$.

\subsection{Heavy metals and main composition of the stones analyzed}

In total, 8 heavy metals were detected in the stones analyzed. The average (SD) number of heavy metals detected per stone was 5 (1.2). Iron (Fe) and strontium ( $\mathrm{Sr}$ ) were detected in all the stones analyzed, regardless of the site and the chemical, and crystalline composition of the stones (Fig. 1). The other heavy metals detected were zinc $(\mathrm{Zn})$ (in 34 stones), copper $(\mathrm{Cu})$ (in 31 stones), bromine $(\mathrm{Br})$ (in 22 stones), rubidium ( $\mathrm{Rb}$ ) (in 10 stones), lead $(\mathrm{Pb})$ (in 8 stones) and nickel ( $\mathrm{Ni}$ ) (in 3 stones). On the peripheral layers of the stones, $\mathrm{Rb}$ had the highest concentration, i.e., an average (SD) $\mathrm{Rb} / \mathrm{Ca}$ ratio of 0.317 (0.93). $\mathrm{Fe}$ and $\mathrm{Sr}$ had an average (SD) proportion in relation to calcium of 0.045 (0.13) and 0.045 (0.06). Likewise, at the heart of stones, the $\mathrm{Rb}, \mathrm{Sr}$ and Fe had the highest concentration with an average (SD) metal / calcium ratio of 0.213 (0.30), $0.174(0.56)$ and $0.106(0.31)$, respectively. There were no differences in the concentration of heavy metals between the center and crown of stones (Table 2).

$\mathrm{Fe}$ and $\mathrm{Sr}$ were detected in all stones analyzed regardless of the place of residence and province of origin of the patients. $\mathrm{Cu}$ (present in $87.1 \%$ of stones of patients living
Table 2 Heavy metals and their proportion in relation to calcium at the periphery and nucleus of stones

\begin{tabular}{lllll}
\hline Heavy metal & $\begin{array}{l}\text { Frequency } \\
\text { (\%) }\end{array}$ & $\begin{array}{l}\text { Average } \\
\text { crown }\end{array}$ & $\begin{array}{l}\text { Average } \\
\text { center }\end{array}$ & $\boldsymbol{p}$ \\
\hline Iron & $36(100.0)$ & $0.045 \pm 0.13$ & $0.106 \pm 0.31$ & 0.323 \\
Strontium & $36(100.0)$ & $0.045 \pm 0.06$ & $0.174 \pm 0.56$ & 0.988 \\
Zinc & $34(94.4)$ & $0.022 \pm 0.05$ & $0.023 \pm 0.05$ & 0.900 \\
Copper & $31(86.1)$ & $0.010 \pm 0.03$ & $0.013 \pm 0.03$ & 0.839 \\
Bromine & $22(61.1)$ & $0.008 \pm 0.01$ & $0.008 \pm 0.01$ & 0.986 \\
Rubidium & $10(27.8)$ & $0.317 \pm 0.93$ & $0.213 \pm 0.30$ & 0.143 \\
Lead & $8(22.2)$ & $0.003 \pm 0.00$ & $0.008 \pm 0.01$ & 0.271 \\
Nickel & $3(8.3)$ & $0.009 \pm 0.01$ & $0.061 \pm 0.08$ & 0.236 \\
\hline
\end{tabular}

in Kinshasa vs. $80 \%$ of stones of those living in the provinces), $\mathrm{Zn}$ (96.8\% in Kinshasa vs. $80 \%$ in provinces), $\mathrm{Br}$ (67, $7 \%$ in Kinshasa vs. $20 \%$ in provinces) and $\mathrm{Ni}(9.7 \%$ in Kinshasa vs. $0 \%$ in provinces) were more frequent in the urinary stones of patients living in Kinshasa. On the other hand, $\mathrm{Rb}$ ( $25.8 \%$ in Kinshasa vs. $40 \%$ in provinces) and $\mathrm{Pb}$ (19.4\% in Kinshasa vs. $40 \%$ in provinces) were more frequent in patients from provinces other than Kinshasa. Stones of patients from the provinces of the western, northern and central-southern regions contained more $\mathrm{Cu}$ and $\mathrm{Br}$ than those of patients from the provinces
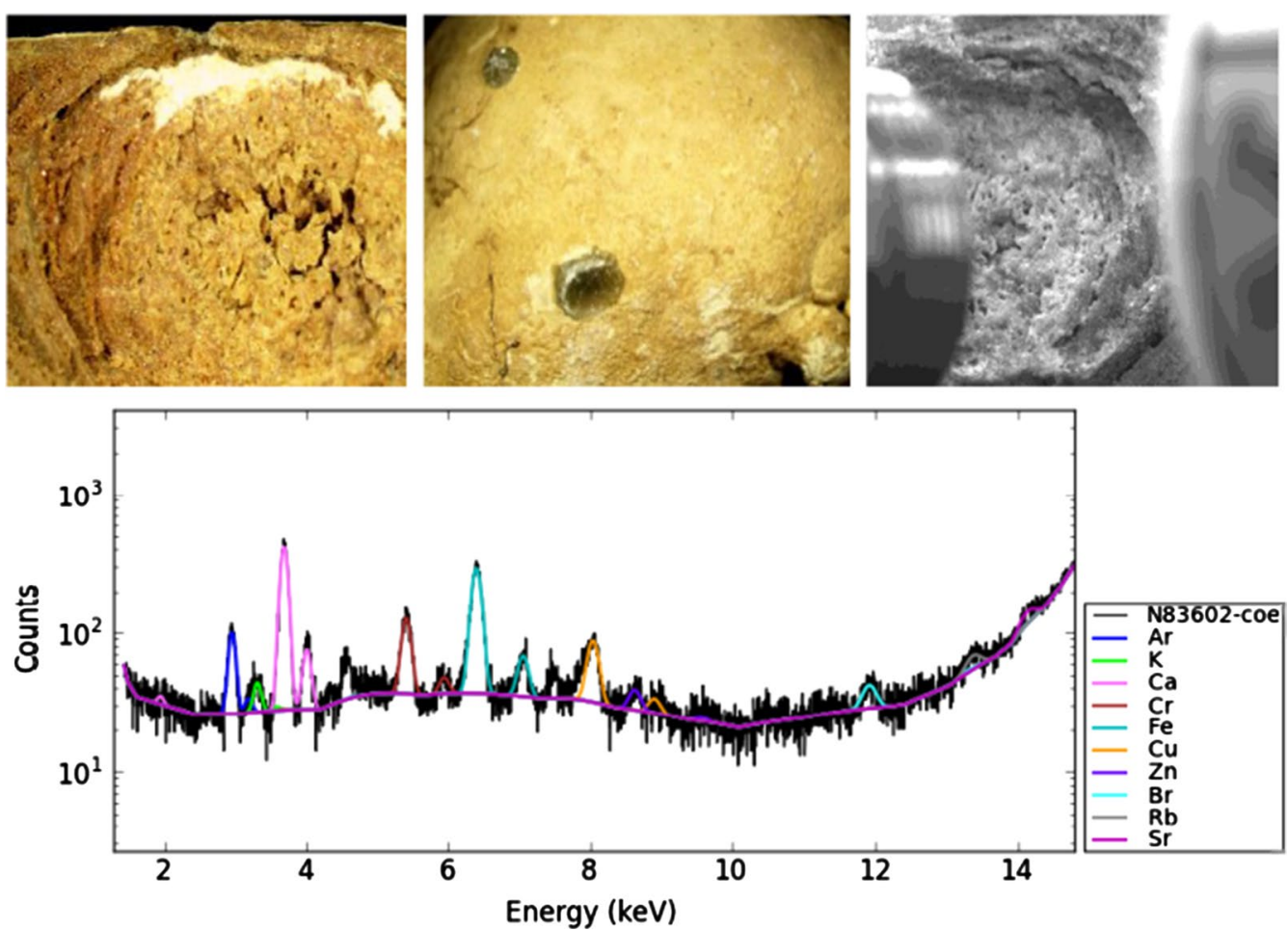

Fig. 1 Illustration of a stone analyzed with its $X$-ray fluorescence spectrum 
of the eastern region. However, the difference was not statistically significant. Zinc was more frequent in stones of patients from the provinces of the western, northern and central-southern regions (93.3\% of those originating from the western part, $100 \%$ of those originating from the north and central-south part vs. $0 \%$ of those originating from the eastern part, $p=0.044)$. $\mathrm{Rb}, \mathrm{Pb}$ and $\mathrm{Ni}$ were more frequent in stones of patients from provinces in the northern region (Table 3).

One stone of whewellite was deemed pure (excluding the protein frame and mucopolysaccharides representing less than $5 \%$ ), others were mixed. The mean number (SD) of components per stone analyzed was 5.0 (1.6). Main components identified stones included whewellite (in 20 stones), weddellite (in 8 stones), anhydrous uric acid (in 5 stones), carbapatite (in one stone), struvite (in one stone) and ammonium urate (in one stone). Compared to males, females had more weddellite stones (36.4\% females vs. $23.5 \%$ males) and fewer whewellite stones (63.6\% females vs. $76.5 \%$ males) (Fig. 2).

Among the oxalo-calcium stones, females had a higher Fe content than males (average Fe / calcium ratio of $0.013 \pm 0.013$ for females vs. $0.005 \pm 0.002$ for males, $p=0.026$ ) (Fig. 3).

Copper, $\mathrm{Zn}, \mathrm{Br}$ and $\mathrm{Rb}$ were identified in both oxalophosphocalcic and organic stones (purines). $\mathrm{Rb}$ had a more affinity with phosphates and purines than with calcium oxalate stones (average $\mathrm{Rb} /$ calcium ratio of $1.496 \pm 2.070$ for phosphates, $0.026 \pm 0.022$ for purines vs. average $\mathrm{Rb} /$ calcium ratio of $0.001 \pm 0.003$ for calcium oxalate, $p<0.001)$. Ni exhibited more affinity for phosphates than with calcium oxalate and purines (Table 4 and Fig. 4).

The means Fe / calcium ratio of $\mathrm{CaOx}$, phosphate and majority purine stones were $0.008 \pm 0.010,0.316 \pm 0.430$ and $0.129 \pm 0.177(\mathrm{p}=0.010)$, respectively, and the means $\mathrm{Sr} /$ calcium ratio of these same majority bodies were $0.035 \pm 0.029,0.255 \pm 0.134$ and $0.020 \pm 0.010$, respectively $(p=0.045)$.

$\mathrm{Fe}$ and $\mathrm{Sr}$ exhibited a higher affinity with weddellite than with whewellite (mean iron / calcium ratio of $0.006 \pm 0.005$ for whewellite vs. $0.019 \pm 0.016$ for weddellite, $p=0.003$ and mean $\mathrm{Sr} /$ calcium ratio of $0.031 \pm 0.026$ for whewellite vs. $0.076 \pm 0.071$ for weddellite, $p=0.029$ ) (Fig. 5).

\section{Discussion}

In this study, we identified eight heavy metals in 36 stones with a mean (SD) of 5 (1.2) per stone. In addition, we found that iron and $\mathrm{Sr}$ were present in all the stones analyzed regardless of their site, the patients' place of residence and the chemical and crystalline composition of the stones. Also, various heavy metals including Rb, iron, $\mathrm{Sr}, \mathrm{Zn}$ and copper were detected at considerable levels.

Table 3 Distribution of heavy metals by place of residence and province of origin of patients

\begin{tabular}{|c|c|c|c|c|c|c|c|c|c|}
\hline \multirow[t]{2}{*}{ Variables } & \multicolumn{2}{|c|}{ Residential homes } & \multirow[t]{2}{*}{$p$} & \multicolumn{4}{|c|}{ Provinces of origin } & \multirow[t]{2}{*}{$p$} & \multirow[t]{2}{*}{ All $n=36(\%)$} \\
\hline & $\begin{array}{l}\text { Kinshasa } \\
n=31(\%)\end{array}$ & $\begin{array}{l}\text { Other provinces } \\
n=5(\%)\end{array}$ & & $\begin{array}{l}\text { Western } \\
n=15(\%)\end{array}$ & $\begin{array}{l}\text { North } \\
n=6(\%)\end{array}$ & $\begin{array}{l}\text { Center-south } \\
n=14(\%)\end{array}$ & $\begin{array}{l}\text { Eastern } \\
n=1(\%)\end{array}$ & & \\
\hline Copper & & & 0.549 & & & & & 0.067 & \\
\hline Yes & $27(87.1)$ & $4(80.0)$ & & $13(86.7)$ & $6(100.0)$ & $12(85.7)$ & $0(0.0)$ & & $31(86.1)$ \\
\hline No & $4(12.9)$ & $1(20.0)$ & & $2(13.3)$ & $0(0.0)$ & $2(14.3)$ & $1(100.0)$ & & $5(13.9)$ \\
\hline Zinc & & & 0.262 & & & & & $0.044^{*}$ & \\
\hline Yes & $30(96.8)$ & $4(80.0)$ & & 14 (93.3) & $6(100.0)$ & $14(100.0)$ & $0(0.0)$ & & $34(94.4)$ \\
\hline No & $1(3.2)$ & $1(20.0)$ & & $1(6.7)$ & $0(0.0)$ & $0(0.0)$ & $1(100.0)$ & & $2(5.6)$ \\
\hline Bromine & & & 0.064 & & & & & 0.404 & \\
\hline Yes & $21(67.7)$ & $1(20.0)$ & & $11(73.3)$ & $3(50.0)$ & $8(57.1)$ & $0(0.0)$ & & $22(61.1)$ \\
\hline No & $10(32.3)$ & $4(80.0)$ & & $4(26.7)$ & $3(50.0)$ & $6(42.9)$ & $1(100.0)$ & & 14 (38.9) \\
\hline Rubidium & & & 0.429 & & & & & 0.541 & \\
\hline Yes & $8(25.8)$ & $2(40.0)$ & & $4(26.7)$ & $3(50.0)$ & $3(21.4)$ & $0(0.0)$ & & $10(27.8)$ \\
\hline No & $23(74.2)$ & $3(60.0)$ & & $11(73.3)$ & $3(50.0)$ & $11(78.6)$ & $1(100.0)$ & & $26(72.2)$ \\
\hline Lead & & & 0.305 & & & & & 0.8585 & \\
\hline Yes & $6(19.4)$ & $2(40.0)$ & & $3(20.0)$ & $2(33.3)$ & $3(21.4)$ & $0(0.0)$ & & $8(22.2)$ \\
\hline No & 25 (80.6) & $3(60.0)$ & & $12(80.0)$ & $4(66.7)$ & 11 (78.6) & $1(100.0)$ & & $28(77.8)$ \\
\hline Nickel & & & 0.629 & & & & & 0.094 & \\
\hline Yes & $3(9.7)$ & $0(0.0)$ & & $0(0.0)$ & $2(33.3)$ & $1(7.1)$ & $0(0.0)$ & & $3(8.3)$ \\
\hline No & $28(90.3)$ & $5(100.0)$ & & 15 (100.0) & $4(66.7)$ & $13(92.9)$ & $1(100.0)$ & & $33(91.7)$ \\
\hline
\end{tabular}

* Likelihood ratio chi-square 


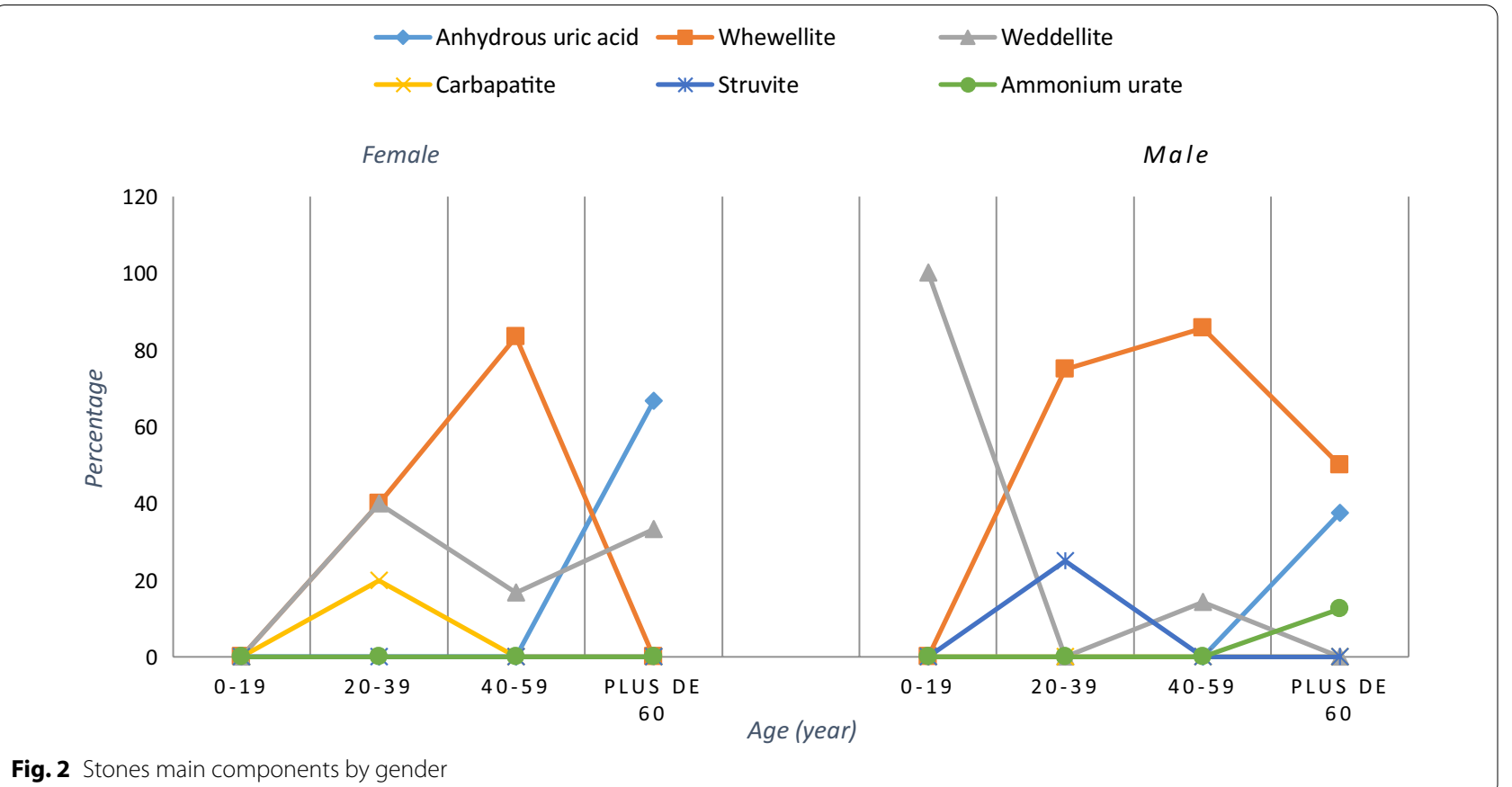

Fig. 2 Stones main components by gender

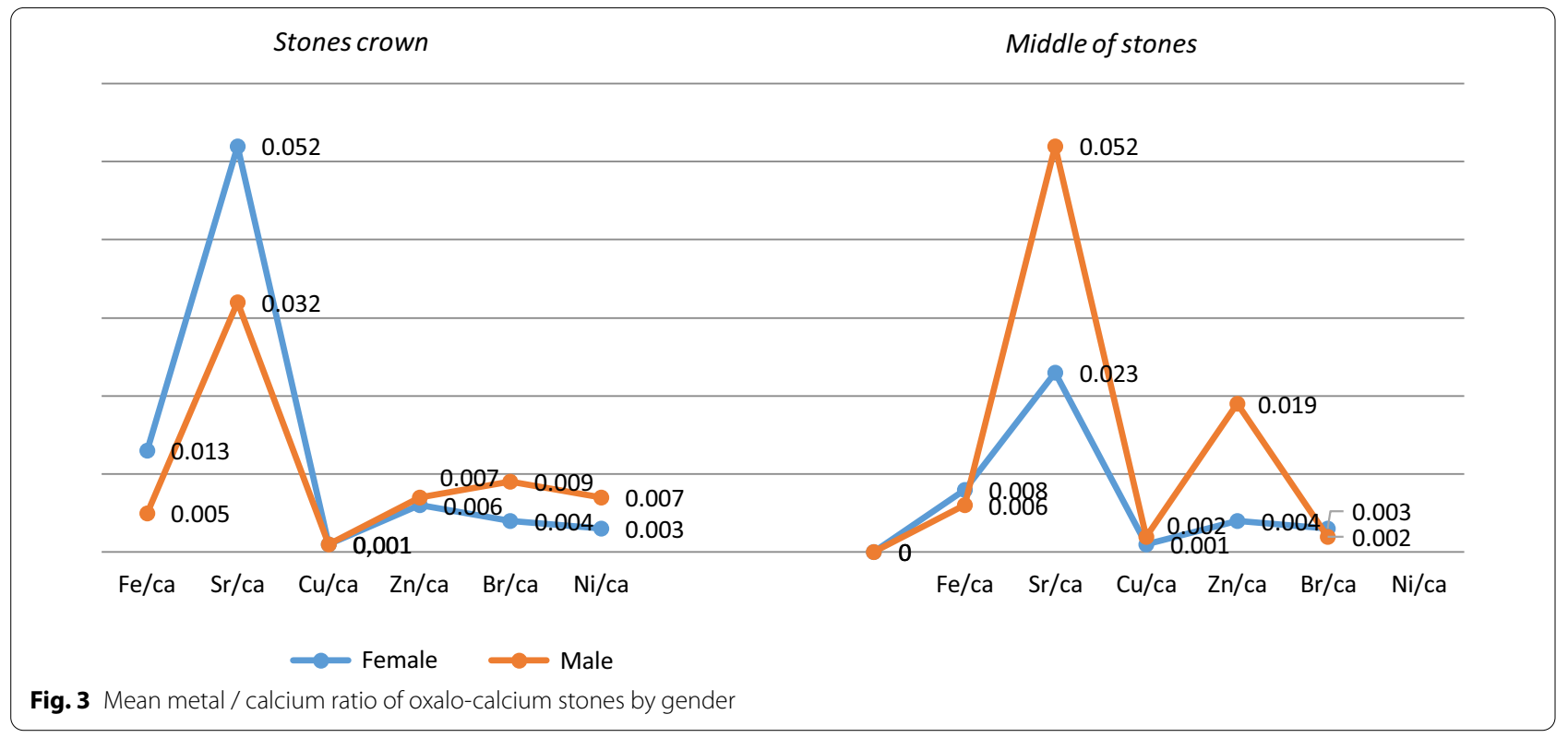

These findings may suggest a possible role of environmental pollution. This is in line with studies conducted elsewhere. In France, a study reported seven heavy metals in 78 stones analyzed [1]. Likewise, a study in Sudan identified eight heavy metals (iron, Ni, copper, $\mathrm{Zn}, \mathrm{Se}, \mathrm{Sr}$, $\mathrm{Br}$ and lead) in 14 kidney stones of urolithiasis patients [19].

Sources of pollution in our regions remain to be determined. Indeed, the main sources of exposure to metals are industrial, domestic and automotive (mining, painting, buildings, contaminated soil, etc.) [20]. Depending on the physicochemical nature or the conditions of use of the metal or its derivatives, absorption can be pulmonary and/or digestive (depending on the size of the particles). Some heavy metals, including lead, are released by the wind in the form of aerosols. They are deposited by rain on the ground or in waterways, where some of them accumulate, are transformed 
Table 4 Distribution of heavy metals according to the main components of stones grouped together

\begin{tabular}{|c|c|c|c|c|c|}
\hline \multirow[t]{2}{*}{ Heavy metal } & \multicolumn{3}{|l|}{ Type of stones } & \multirow[t]{2}{*}{ All $n=36(\%)$} & \multirow[t]{2}{*}{$p$} \\
\hline & $\begin{array}{l}\text { Calcium oxalate } n=28 \\
(\%)\end{array}$ & Phosphates $n=2(\%)$ & Purines $n=6$ & & \\
\hline Copper & & & & & 0.436 \\
\hline Oui & $23(82.1)$ & $2(100.0)$ & $6(100.0)$ & $31(86.1)$ & \\
\hline Non & $5(17.9)$ & $0(0.0)$ & $0(0.0)$ & $5(13.9)$ & \\
\hline Zinc & & & & & 0.739 \\
\hline Oui & $26(92.9)$ & $2(100.0)$ & $6(100.0)$ & $34(94.4)$ & \\
\hline Non & $2(7.1)$ & $0(0.0)$ & $0(0.0)$ & $2(5.6)$ & \\
\hline Bromine & & & & & 0.4639 \\
\hline Oui & $16(57.1)$ & $1(50.0)$ & $5(83.3)$ & $22(61.1)$ & \\
\hline Non & $12(42.9)$ & $1(50.0)$ & $1(16.7)$ & 14 (38.9) & \\
\hline Rubidium & & & & & $<0.001^{*}$ \\
\hline Oui & $3(10.7)$ & $2(100.0)$ & $5(83.3)$ & $10(27.8)$ & \\
\hline Non & $25(89.3)$ & $0(0.0)$ & $1(16.7)$ & $26(72.2)$ & \\
\hline Lead & & & & & 0.230 \\
\hline Oui & $8(28.6)$ & $0(0.0)$ & $0(0.0)$ & $8(22.2)$ & \\
\hline Non & $20(71.4)$ & $2(100.0)$ & $6(100.0)$ & $28(77.8)$ & \\
\hline Nickel & & & & & 0.076 \\
\hline Oui & $2(7.1)$ & $1(50.0)$ & $0(0.0)$ & $3(8.3)$ & \\
\hline Non & 26 (92.9) & $1(50.0)$ & $6(100.0)$ & $33(91.7)$ & \\
\hline
\end{tabular}

* Likelihood ratio chi-square

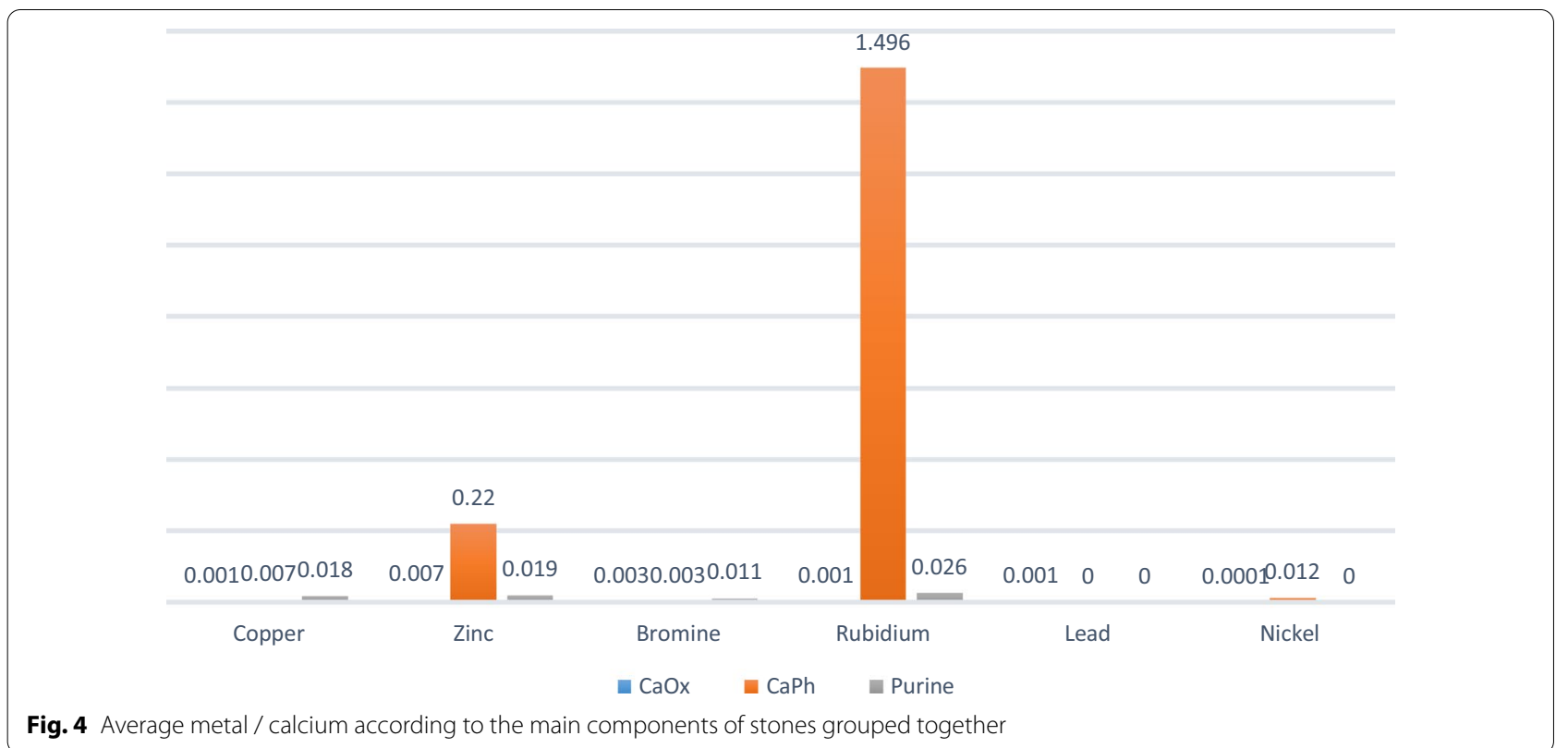

and will finally be retained by organic matter, mostly plants (leaves, grass, flower, lichens) [20]. Hence, the interest in measuring these metals in drinking water, in various vegetables and fruits consumed in the DRC.
We found that $\mathrm{Rb}$ had higher affinity with phosphates and purines than with calcium oxalate. This association was also observed with $\mathrm{Cu}$ and $\mathrm{Zn}$, but was not statistically significant. Ni tended to have higher affinity with 


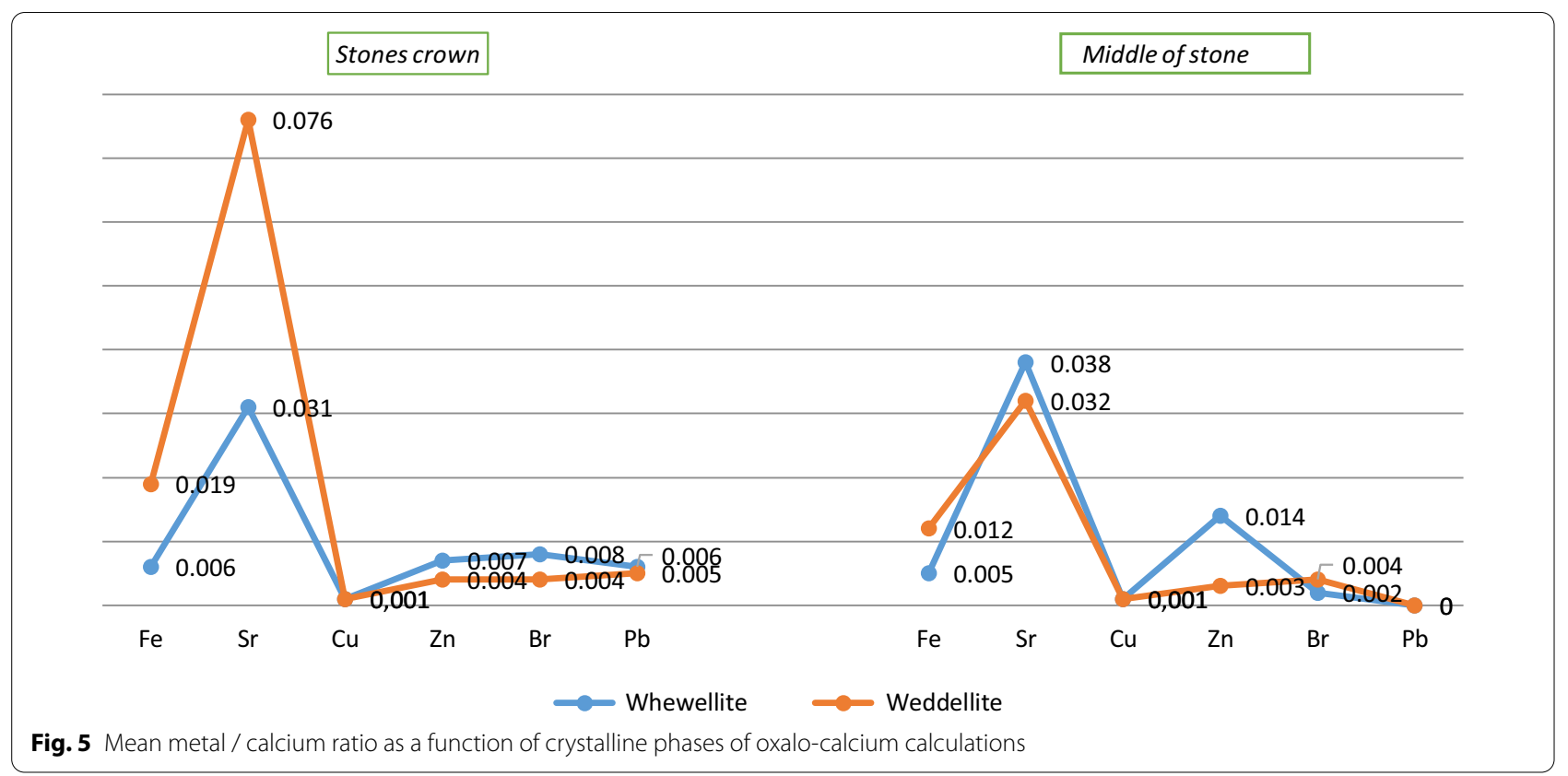

phosphates than with calcium oxalate and purines, whereas lead tended to have higher affinity with calcium oxalate than with phosphates and purines. A study conducted in France found that $\mathrm{Zn}$ and Sr were particularly linked to calcium phosphates than to calcium oxalate, while iron, $\mathrm{Rb}$ and $\mathrm{Pb}$ were more abundant in calcium stones than in struvite, uric acid or cystine stones [1]. These authors explained the difference in the affinity of heavy metals between calcium and non-calcium stones by the similarity between the ionic charge and the size of $\mathrm{Zn}, \mathrm{Sr}$ and calcium, which allows these elements to substitute for calcium in the crystal lattice $[1,21]$. Thus, divalent metal ions such as $\mathrm{Zn}$ and $\mathrm{Sr}$ are probably the most suitable to be incorporated in stones containing calcium [1]. Yunhe et al. [6] in Taiwan also found $\mathrm{Zn}, \mathrm{Ni}$ and Arsenic to be significantly higher in calcium phosphorus stones than in calcium oxalate or uric acid stones.

We believe that the difference in content and affinity of heavy metals and the various components of stones observed between our study and others is probably due to the high heterogeneity of stones in our study. Indeed, in this study, most stones were mixed with a high average number of components per stone $(5.0 \pm 1.6)$. It is well known that mixed stones of calcium oxalate and uric acid contain intermediate amounts of heavy metals [1]. Usually, higher amounts of heavy metals are only found in inorganic stones, i.e., calcium oxalate, calcium phosphate and struvite, while only small amounts are found in the organic phases (uric acid and cystine stones) [1]. Additionally, the use of the metal / calcium ratio to assess the content of heavy metals might explain the higher levels of metals in purine stones observed in this study.

It should also be mentioned that the higher Fe content in stones could result from the inhibitory properties of Iron $3+$ on the crystallization of calcium oxalate $[4,22]$ and possibly from the trapping of $\mathrm{Fe}$ ions on the crystal surface [1].

It is assumed that weddellite retains more heavy metals than whewellite and this is partly explained by the crystalline conversion of weddellite to whewellite which could be accompanied by the release of heavy metals in the medium. In addition, whewellite can crystallize in a particular biochemical environment (hyperoxaluria with a low calcium / oxalate ratio in the urine) [23]. Our findings revealed that $\mathrm{Fe}$ and $\mathrm{Sr}$ exhibited a higher affinity with weddellite than with whewellite. Thus, females with more weddellite stones exhibited stones with a higher content in Fe than males (average iron / calcium ratio of $0.013 \pm 0.013$ for the woman vs. $0.005 \pm 0.002$ for the man, $p=0.026$ ).

In line with a previous study [1], we found no difference in heavy metal content between the nucleus and the peripheral layers of the stones analyzed. This may suggest that heavy metals play no role in crystal induction. However, the role of trace heavy metals in the pathogenesis of kidney stones is not always clear [24]. Indeed, Ramaswamy et al. [25] working on heavy metals in 2015 showed that the net lithogenic effects of zinc, copper, iron and manganese were still uncertain [25]. Also, Komleh et al. [26] after analysis of serum and urine concentrations of 
zinc, copper and manganese in 56 lithiasis patients and 39 healthy controls, found that urinary zinc concentrations were higher in lithiasis patients, whereas those of copper and manganese were lower. Similarly, Ferraro et al. [24] showed that total non-dietary copper intake was marginally associated with a higher risk of stones (combined HR 1.14, 95\% CI 1.02-1.28, $p=0.01$ ) and in their series they did not find a statistically significant association between total manganese and copper intake and urinary supersaturation [24].

In addition to the possible role of heavy metals in crystalline induction, Sun et al. [27] recently described that several biomarkers of exposure to arsenic, cadmium, lead and mercury were associated with the likelihood of developing kidney stones in adults.

Given that provinces other than Kinshasa are centers of extensive mining exploitation, we would expect to find more heavy metals in patients living in these areas. However, our findings revealed that $\mathrm{Fe}$ and $\mathrm{Sr}$ were present in all stones regardless of place of residence. Additionally, other heavy metals were more frequent in the urinary stones of patients living in Kinshasa compared to other provinces. This may be explained, at least partially, by the urban pollution. Kinshasa is a very crowded city with over 10 million population. Toxic substances including heavy metals from motor vehicle emissions and various factories can contaminate food crops consumed by the population. Furthermore, most people do not have piped drinking water connections on premises and millions still rely on direct use of surface water exposing themselves to waterborne exposures including heavy metals from contaminated topsoil. Another reason is that this study was underpowered to detect any differences.

The main limitation of this study is the small sample size. Regardless, this study is the first of its kind in the DRC to investigate the presence of heavy metals in stones. This study would likely contribute to the debate on the level of pollution in our environment. Further studies with more robust sample size are required to determine the impact of heavy metals in the occurrence of kidney disease in lithiasis patients in our environment. A recent single-center study in the DRC reported that $15.5 \%$ of urolithiasis patients had renal failure [28], and the nephrotoxic effect of certain heavy metals such as arsenic, lead, mercury and cadmium is well known [27].

\section{Conclusion}

We analyzed the presence of heavy metal in kidney stones from thirty-six patients using X-ray Fluorescence by $\mu$-Synchrotron Radiation. Overall, stones from our patients contained a sizable number of heavy metals and these findings may suggest environmental pollution rather than crystalline induction factors. Fe and $\mathrm{Sr}$ were found in all stones analyzed regardless of the site of the stones, the place of residence of the patients, their province of origin or the chemical or crystalline composition of the stones. Other heavy metals including iron, $\mathrm{Sr}$, copper, $\mathrm{Zn}, \mathrm{Br}$, lead and $\mathrm{Ni}$ were also detected in oxalo-phosphocalcic stones. Larger and more robust studies are needed to confirm these findings.

\section{Abbreviation \\ DRC: Democratic Republic of Congo; HMA: Hydroxy methyl acid; Fe: Iron; Sr: Strontium; Zn: Zinc; Cu: Copper; Br: Bromine; Rb: Rubidium; Pb: Lead; Ni: Nickel.}

\section{Supplementary Information}

The online version contains supplementary material available at https://doi. org/10.1186/s12301-021-00188-0.

Additional file 1. Different stones analyzed by X-ray fluorescence and heavy metals detected in each stone.

\section{Acknowledgements}

The authors sincerely thank the Department of Functional Explorations of the Tenon Hospital in Paris, the Solids Physics Laboratory of the Paris-Sud University, the staff of the Urology Department of the University Clinics of Kinshasa, as well as all partner hospitals and doctors who agreed to collaborate with us in this study.

\section{Authors' contributions}

PKDD, DMM and MD designed, collected, interpreted, wrote and corrected the manuscript. ANM analyzed the data, read and corrected the article. MD and JPH supervised, interpreted and edited the article. All authors have read and approved the final version of the article.

Funding

The authors received no funding for this study.

Availability of data and materials

The datasets used and/or analyzed during the current study are available from the corresponding author on reasonable request.

\section{Declarations}

\section{Ethics approval and consent to participate}

This study was approved by the ethics committee of the School of Public Health of the University of Kinshasa (approval number: ESP / CE / 29/2020). Participation of human research subjects conformed to institutional review board guidelines, applicable laws and the World Medical Association Declaration of Helsinki. Written informed consent was waived owing to the use of deidentified retrospective data.

\section{Consent for publication}

Not applicable.

Competing interests

The authors declare that they have no competing interests.

\section{Author details}

${ }^{1}$ Department of Urology, Kinshasa University Hospital, Faculty of Medicine, University of Kinshasa, Kinshasa, Democratic Republic of Congo. ${ }^{2}$ Department of Clinical Biology, Kinshasa University Hospital, Kinshasa, Democratic Republic of Congo. ${ }^{3}$ Department of Functional Investigations, TENON Hospital, Paris, France. 
Received: 14 March 2021 Accepted: 12 June 2021

Published online: 05 July 2021

\section{References}

1. Bazin D, Chevallier P, Matzen G, Jungers P, Daudon M (2007) Heavy elements in urinary stones. Urol Res 35:179-184

2. Durak I, Kilic Z, Sahin A, Akpoyraz M (1992) Analysis of calcium, iron, copper and zinc contents of nucleus and crust parts of urinary calculi. Urol Res 20:23

3. Grases F, Genestar C, Mill A (1989) The influence of some metallic ions and their complexes on the kinetics of crystal growth of calcium oxalate. J Crystal Growth 94:507

4. Meyer JL, Thomas WC Jr (1982) Trace metal-citric acid complexes as inhibitors of calcification and crystal growth. II. Effects of Fe (III), $\mathrm{Cr}$ (III) and Al (III) complexes on calcium oxalate crystal growth. J Urol 128:1376

5. Perk H, Ahmet Serel T, Kosar A, Deniz N, Sayin A (2002) Analysis of the trace element contents of inner nucleus and outer crust parts of urinary calculi. Urol Int 68:286

6. Yunhe Y, Borshuh C, Changchung CL, Hsiuling C (2018) Heavy metal components in blood and urinary stones of urolithiasis patients. Biol Trace Elem Res 185(2):266-274

7. Hannache B, Boutefnouchet A, Bazin D, Daudon M, Foy E, Rouzière S, Dahdouh A (2015) Nature et rôle des éléments traces dans les calculs urinaires [Presence and role of trace elements in urinary calculi]. Prog Urol 25(1): 22-6. French. doi: https://doi.org/10.1016/j.purol.2014.09.038. Epub 2014 Nov 6. PMID: 25450750.

8. Keshavarzi B, Yavarashayeri N, Irani D, Moore F, Zarasvandi A, Salari M (2015) Trace elements in urinary stones: a preliminary investigation in Fars province. Iran Environ Geochem Health 37(2):377-389. https://doi.org/10. 1007/s10653-014-9654-z (Epub 2014 Nov 30 PMID: 25433503)

9. Hesse A, Dietze HJ, Berg W, Hienzsch E (1977) Mass spectrometric trace element analysis of calcium oxalate uroliths. Eur Urol 3:359

10. Levinson AA, Nosal M, Davidman M, Prien EL Sr, Prien EL Jr, Stevenson RG (1978) Trace elements in kidney stones from three areas in the United States. Invest Urol 15:270

11. Wandt MAE, Pougnet MAB (1986) Simultaneous determination of major and trace elements in urinary calculi by microwave-assisted digestion and inductively coupled plasma atomic emission spectrometric analysis. Analyst 111:1249

12. Joost J, Tessadri R (1987) Trace element investigations in kidney stone patients. Eur Urol 13:264

13. Durak I, Kilic Z, Perk H, Sahin A, Yurtarslani YA, Küpeli S, Akpoyraz M (1990) Iron, copper, cadmium, zinc and magnesium contents of urinary tract stones and hair from men with stone disease. Eur Urol 17:243

14. Hofbauer J, Stevan I, Höbarth K, Vujicic G, Schwetz H, Reich G, Zechner O (1991) Trace elements and urinary stone formation: new aspects of the pathological mechanism of urinary stone formation. J Urol 145:93

15. Tomicic C, Vernez D, Belem T, Berode M (2011) Human mercury exposure associated with small-scale gold mining in Burkina Faso. Int Arch Occup Environ Health 84(5):539-546. https://doi.org/10.1007/s00420-011-0615-x
16. ParuchuriY Siuniak A, Johnson N, Levin E, Mitchell K, Goodrich JM et al (2010) Occupational and environmental mercury exposure among smallscale gold miners in the Talensi-Nabdam District of Ghana's Upper East region. Sci Total Environ 408(24):6079-6085. https://doi.org/10.1016/j. scitotenv.2010.08.022

17. Baeuml J, Bose-O'Reilly S, Matteucci Gothe R, Lettmeier B, Roider G, Drasch G et al (2011) Human biomonitoring data from mercury exposed miners in six artisanal small-scale gold mining areas in Asia and Africa. Minerals 1(1):122-143. https://doi.org/10.3390/min 1010122

18. Bose-O'Reilly S, Bernaudat L, Siebert U, Roider G, Nowak D, Drasch G (2017) Signs and symptoms of mercury-exposed gold miners. Int J Occup Med Environ Health 30(2):249-269. https://doi.org/10.13075/ijomeh. 1896.00715 (Epub 2017 Mar 22 PMID: 28366955)

19. Eisa M, Pineda-Vargas CA, Sami EES, Rodgers AL (2018) Investigations of trace and toxic elements of kidney stones from two different sudanese areas by $\mu$-PIXE using nuclear microprobe (NMP). Appl Radiat Isot 131:58-61

20. Dehon B, Nisse C, Lhermitte M, Haguenoer J-M (2001) Métaux et Médecine du Travail. Ann Toxicol Anal 13(3):203-219

21. Khattech I, Jemal M (1997) A complete solid-solution exists between Ca and $\mathrm{Sr}$ in synthetic apatite. Thermochim Acta 298:23

22. Munoz JA, Valiente M (2005) Effects of trace metals on the inhibition of calcium oxalate crystallization. Urol Res 33:267

23. Daudon M, Jungers $P$, Lacour B (2004) Intérêt clinique de l'étude de la cristallurie. Ann Biol Clin 62:379

24. Ferraro PM, Gambaro G, Curhan GC, Taylor EN (2018) Intake of Trace Metals and the Risk of Incident Kidney Stones. J Urol 199(6): 1534-1539. doi: https://doi.org/10.1016/j.juro.2018.01.077. Epub 2018 Jan 31. PMID: 29391176; PMCID: PMC6689148.

25. Ramaswamy K, Killilea DW, Kapahi P et al. (2015) L'élémentome des calculs urinaires à base de calcium et son rôle dans la lithiase urinaire. Nat Rev Urol 12 : 543. [Article gratuit de PMC ] [PubMed ] [Google Scholar]

26. Komleh K, Hada P, Pendse AK et al (1990) Zinc, cuivre et manganèse dans le sérum, I'urine et les calculs. Int Urol Nephrol 22 : 113. [PubMed] [Google Scholar]

27. Sun Y, Zhou Q, Zheng J (2019) Métaux néphrotoxiques du cadmium, du plomb, du mercure et de l'arsenic et probabilité de calculs rénaux chez l'adulte : une analyse exposition-réponse de la NHANES 2007-2016. Environ Int 132:105115

28. Diangienda KD, Moningo M, Mafuta M, Punga M, Lufuma LN, Daudon M (2019) Profil épidémiologique des calculs urinaires aux Cliniques Universitaires de Kinshasa. Ann Afr Med 12(2):3220-3228

\section{Publisher's Note}

Springer Nature remains neutral with regard to jurisdictional claims in published maps and institutional affiliations.

\section{Submit your manuscript to a SpringerOpen ${ }^{\circ}$ journal and benefit from:}

- Convenient online submission

- Rigorous peer review

- Open access: articles freely available online

- High visibility within the field

Retaining the copyright to your article

Submit your next manuscript at springeropen.com 